\title{
Aspiration of superabsorbent polymer beads resulting in focal lung damage: a case report
}

\author{
Nasser Alharbi $^{1^{*}}$ and Maryam Dabbour ${ }^{2}$
}

\begin{abstract}
Background: Concerns have recently been raised about reported incidents of intestinal obstruction following ingestion of Superabsorbent polymer (SAP) beads. Texas Poison Centers reported 110 cases of superabsorbent polymer bead ingestions between 2011 and 2016 (Pediatr Emerg Care 35:426-7, 2019). Furthermore, cases of related auditory complications following the placement of SAP beads into the external auditory canal have also been reported. Here, we report the first case of significant airway damage secondary to the ingestion of a SAP bead (Orbeez), which was aspirated and then overlooked. Further, we hypothesized that the capability of the bead to expand in size once exposed to water from the respiratory mucous may contribute to airway damage.

Case presentation: A 3-year-old boy presented to our hospital with persistent cough and recurrent hospitalizations to the general ward and intensive care unit. The boy was diagnosed with focal lung bronchiectasis in the left lower lobe, which occurred after the patient aspirated an Orbeez bead before a year. The bead was removed using flexible bronchoscopy and a retrieval basket.

Conclusion: Orbeez beads are commonly ingested by young children resulting in gastrointestinal obstruction. The beads can easily be aspirated by children and overlooked by their caregivers and physicians for long periods of time due to their small size. The bead can cause significant airway damage after multiplying in size when coming into contact with respiratory mucus which consists of $95 \%$ water.
\end{abstract}

Keywords: Orbeez, Water-absorbing bead, Bronchiectasis, Foreign body aspiration

\section{Background}

Foreign body aspiration is relatively common public health problem. Accounting for $7 \%$ of accidental deaths in children under 4 years of age $[1,2]$. Despite that $25 \%$ of the inhaled foreign body are non-organic material, they represent the major indication for surgical interventions $[3,4]$. The symptoms resulting from FB aspiration are related to size, shape, and nature of the foreign body [5]. Whereas organic foreign bodies cause airway inflammation, an inorganic foreign body may go undetected

\footnotetext{
* Correspondence: dr4p2015@gmail.com; nsalharbi@ksu.edu.sa 'Department of Pediatrics, College of Medicine, King Saud University and King Saud University Medical City, Riyadh, Saudi Arabia

Full list of author information is available at the end of the article
}

for a long time without causing any remarkable symptom [2-4].

The longer the FB remains in the bronchial tree the greater the chances are of it becoming dislodged from the bronchus and impacting the larynx, with risk being higher in inorganic FBs [6].

Superabsorbent polymer (SAP) bead capable of increasing its original size up to 200 times once placed in water [7]. It has the appearance of candy, and thus, is commonly ingested by children [8,9]. From 2011 to 2016, the Texas Poison Center Network (TPCN) reported 110 incidents of SAP bead ingestion. Half of these incidents occurred in school-aged children, and around $30 \%$ of these incidents happened at school [8].

(C) The Author(s). 2020 Open Access This article is licensed under a Creative Commons Attribution 4.0 International License, which permits use, sharing, adaptation, distribution and reproduction in any medium or format, as long as you give appropriate credit to the original author(s) and the source, provide a link to the Creative Commons licence, and indicate if changes were made. The images or other third party material in this article are included in the article's Creative Commons licence, unless indicated otherwise in a credit line to the material. If material is not included in the article's Creative Commons licence and your intended use is not permitted by statutory regulation or exceeds the permitted use, you will need to obtain permission directly from the copyright holder. To view a copy of this licence, visit http://creativecommons.org/licenses/by/4.0/. The Creative Commons Public Domain Dedication waiver (http://creativecommons.org/publicdomain/zero/1.0/) applies to the data made available in this article, unless otherwise stated in a credit line to the data. 
Serious intestinal obstruction following the ingestion of these beads has been reported [7, 10]. A brand of SAP beads called Water Balz was recalled by the U.S. Consumer Product Safety Commission in 2012 due to its potential hazard on the gastrointestinal system [8]. Cases of SAP bead insertion into the auditory canal have been reported as well, in one incident, a young girl experienced significant external auditory canal and cochlear erosion with profound sensorineural hearing loss as a result of an overlooked SAP in the right ear [11, 12].

In this study, we report the first case of significant focal lung damage as a result of an Orbeez bead ingestion which expanded in size after coming into contact with lower airway secretions. Thus, this study necessitates spreading public awareness of the potential danger of SAP beads.

\section{Case presentation}

A 3-year-old boy was referred to the King Faisal Specialist Hospital and Research Center (KFSH\&RC) from the regional hospital in Al-Ahsa region in the eastern province of Saudi Arabia. The patients experienced recurrent chest infections associated with a persistent wet cough which resulted in four hospitalizations over the last year. The child was born uneventfully after stable pregnancy and had no remarkable background history in the first 2 years of his life apart from infrequent mild upper respiratory tract infections without symptoms, suggestive of a lower respiratory tract infection. Shortly after his second birthday, the boy had the first onset of lower respiratory tract infections and presented to the local hospital with fever, tachypnea, and respiratory distress, significant enough to require ICU admission. He responded partially to the initial regimen with oxygen therapy, systemic antibiotics, and systemic steroid and nebulized bronchodilators during the hospitalization. His cough persisted after he was discharged from the hospital and he soon suffered from additional attacks during which his symptoms worsened. His symptoms included respiratory distress, an aggravated cough, and hypoxia, and required frequent emergency visits and a total of 4 hospitalizations over the course of 1 year. The patient's parents are nonconsanguineous, and there was no history of respiratory infections or symptoms in the family. Upon examination of the patient's immune system, test results showed normal immunoglobulin levels and normal lymphocyte markers. A computed tomography (CT) scan of the chest (Fig. 1) indicated multiple cystic changes within the posterior segment of left lower lobe, which most likely represented bronchiectasis changes. FB ingestion was suspected after radiology; however, congenital lung malformation could not be

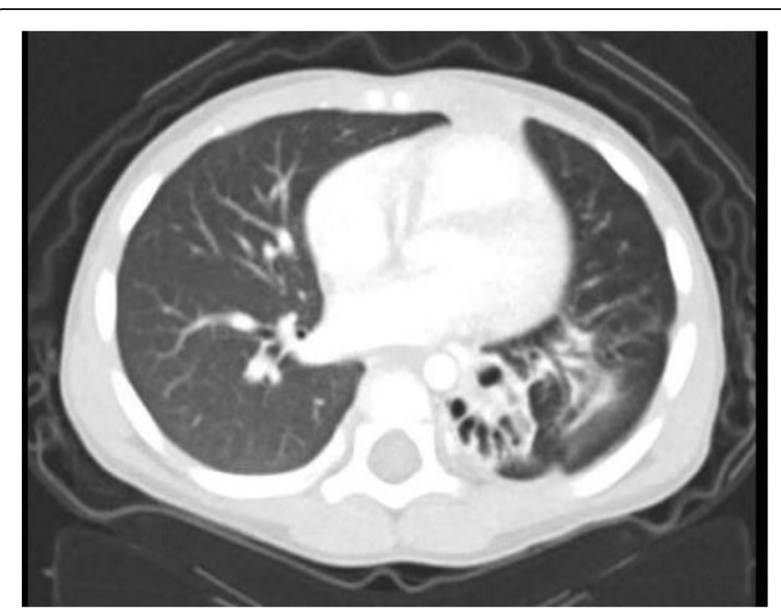

Fig. 1 Chest CT showed a significant damage of the affected segment

ruled out. At this point, the clinical and radiological presentation were suggestive of a foreign body had been ingested by the child and was overlooked. Consequently, the child was referred to our facility where we performed flexible bronchoscopy after the boy had been ill for 1 year.

Clinical examination performed at our facility demonstrated a normal oxygen saturation on room air. There was a decrease in air entry in the left lower zone with no adventitious sounds. Initial chest $\mathrm{x}$-ray (Fig. 2) showed a significant left lower lobe consolidation with Bronchiectasis. Flexible bronchoscopy was performed under general anesthesia, and the patient was intubated by an endotracheal tube in the operating room. A sphereshaped foreign body (Fig. 3) was identified in the left lower lobe posterior segment. The patient's parents were certain that the foreign body represented an Orbeez ball.

An attempt was made to remove the foreign body using a retrieval basket and a flexible scope. Unfortunately, the foreign body was squashed and fragmented into smaller pieces, which required the removal of each piece using the retrieval basket. Eventually, all fragments were removed successfully. We observed that granulation tissue was causing a significant obstruction of the left lower lobe posterior segment airway, to the extent that we could not pass the scope through it. After reconstructing the pieces of the foreign body, the patient's parent indicated that it appeared much larger than its original size. The fragmented pieces were reviewed by a pathologist who confirmed the inorganic nature of the foreign body. At an evaluation after 6 months following the removal of the foreign body the child's symptoms were minimal, with no additional hospitalizations recorded. His chest X-ray demonstrated a persistent bronchiectasis in left lower lobe with interval improvement in the previously noted consolidation (Fig. 4). 


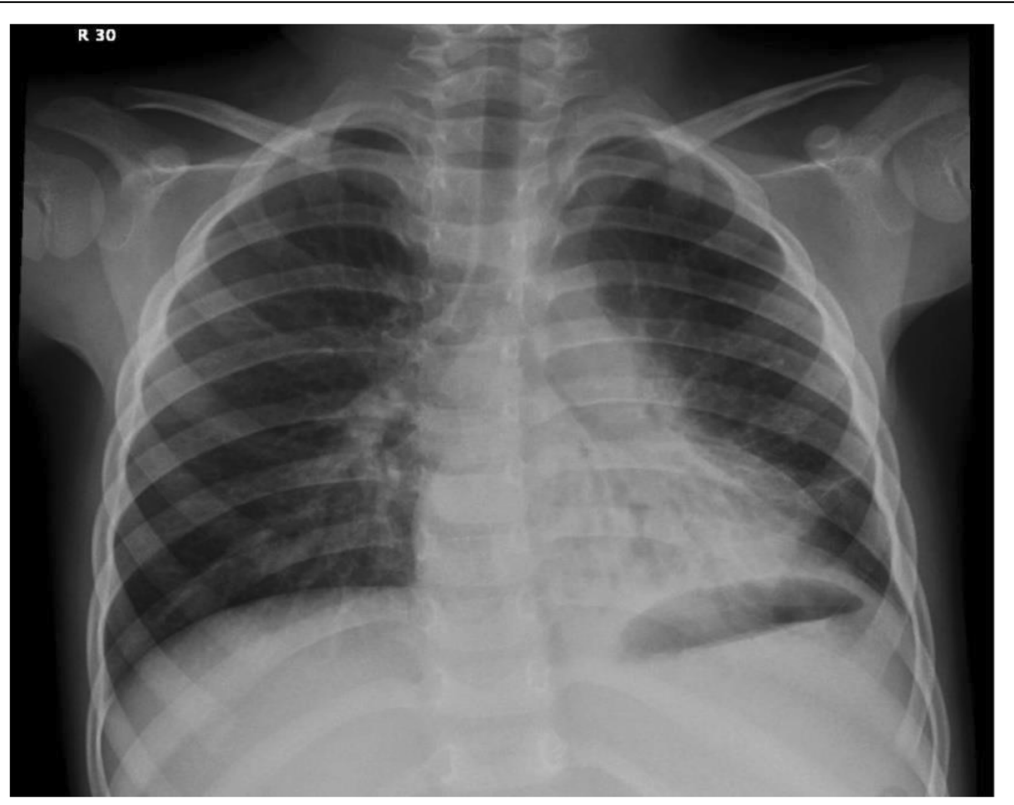

Fig. 2 Chest X-ray before the bronchoscopy showing a significant lower lobe consolidation with Bronchiectasis in in the same lobe

\section{Discussion and conclusion}

SAP beads are small round objects made of inorganic material. They are an inexpensive and widely available children's toy with the appearance of candy [7].

Concerns have been raised after various reports of intestinal obstruction following ingestion of these beads $[7,10]$.

Our study described a case in which the immediate symptoms were unremarkable. Nevertheless, after coming into contact with respiratory mucus which consists of $95 \%$ water, the beads increased in size, causing damage to the lungs [13]. If swallowed, the beads have the potential to remain undetected for long periods of time, our study described a case in which the immediate symptoms were unremarkable. In this case report, the patient developed significant focal bronchiectasis as a result of SAP bead ingestion [13]. Using flexible

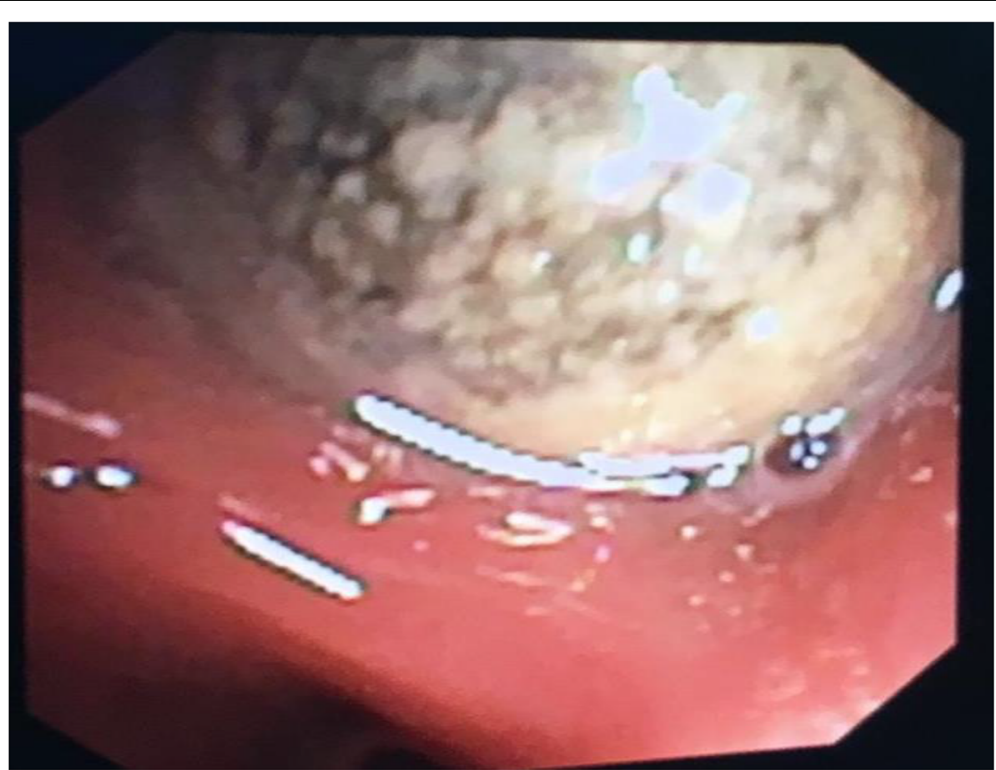

Fig. 3 A granulation tissue covered the object blocking the airway completely, causing pressure over the adjacent wall and squeezing the rest of the airways 


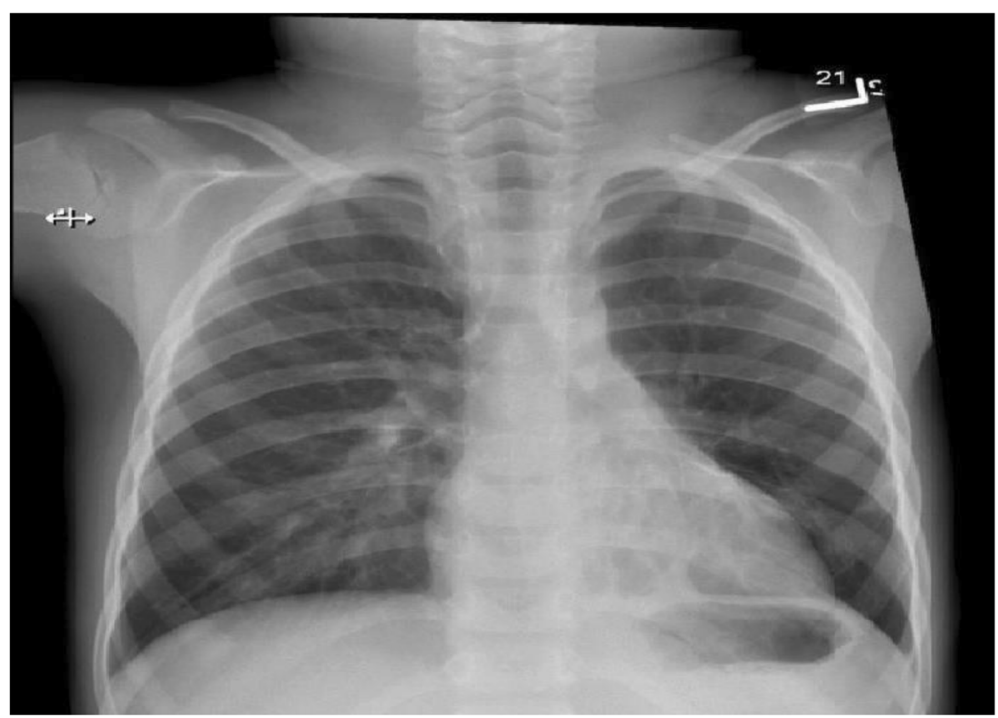

Fig. 4 Chest X-Ray 6 months after Bronchoscopy showing a significant varicose bronchiectasis in the left lower lobe with interval improvement of the consolidation in the same lobe

bronchoscopy and a retrieval basket to retrieve the $\mathrm{FB}$ can be a reasonable first line intervention.

Age restriction and parent observation are not an effective way to prevent these SAP ingestion from occurring, as nearly half of the reported incidents occurred in school-aged children, with $30 \%$ occurring while the children were at school [8].

Thus far, studies have reported that toys such as SAP beads to cause harm to the intestines, the external auditory canal, and as in our case, the respiratory system. We suspect that if stuck in the larynx and enlarged after absorbing water, SAP beads may result in a catastrophic sequelae.

For the above mentioned reasons, we propose recalling all brands of SAP beads from markets. In the meantime, we suggest that every incidence of complications following the ingestion of SAP beads be reported.

\section{Abbreviations}

FB: foreign body; KFSH\&RC: King Faisal specialist hospital and research center; ICU: Intensive Care Unit; CT: computed tomography; SAP: Superabsorbent Polymer

\section{Acknowledgments}

We are grateful to the family who agreed to share the patient's information in this report.

\section{Authors' contributions}

NSA analyzed and interpreted the patient data and drafted the final manuscript. MD contributed to gathering patient data, reviewed the final manuscript and was a major contributor in writing the manuscript. Both authors read and approved the final manuscript.

\section{Availability of data and materials}

Data sharing is not applicable to this report as no data sets were generated or analyzed.

Ethics approval and consent to participate Not applicable.

\section{Consent for publication}

Written informed consent was obtained from the patient/parents/legal guardians for publication of this Case Report and any accompanying images and videos. A copy of the written consent is available for review by the Editor of this journal.

\section{Competing interests}

The authors declare that they have no competing interests.

\section{Author details}

'Department of Pediatrics, College of Medicine, King Saud University and King Saud University Medical City, Riyadh, Saudi Arabia. ${ }^{2}$ Pediatric Pulmonology, Prince Sultan Military Medical City, Riyadh, Saudi Arabia.

Received: 3 November 2019 Accepted: 21 May 2020

Published online: 29 May 2020

\section{References}

1. Fidkowski CW, Zheng $\mathrm{H}$, Firth PG. The anesthetic considerations of tracheobronchial foreign bodies in children: a literature review of 12,979 cases. Anesth Analg. 2010;111(4):1016-25.

2. Brkic F, Umihanic S, Altumbabic H, Ramas A, Salkic A, Umihanic S, et al. Death as a consequence of foreign body aspiration in children. Med Arch. 2018;72(3):220-3.

3. Foltran F, Ballali S, Passali FM, Kern E, Morra B, Passali GC, et al. Foreign bodies in the airways: a meta-analysis of published papers. Int J Pediatr Otorhinolaryngol. 2012;76(Suppl 1):S12-9.

4. Boufersaoui A, Smati L, Benhalla KN, Boukari R, Smail S, Anik K, et al. Foreign body aspiration in children: experience from 2624 patients. Int J Pediatr Otorhinolaryngol. 2013;77(10):1683-8.

5. Passali D, Lauriello M, Bellussi L, Passali GC, Passali FM, Gregori D. Foreign body inhalation in children: an update. Acta Otorhinolaryngol Ital. 2010; 30(1):27-32.

6. Rodriguez H, Cuestas G, Botto H, Nieto M, Cocciaglia A, Passali D, et al. Complications in children from foreign bodies in the airway. Acta Otorrinolaringol Esp. 2016;67(2):93-101. 
7. Fuger M, Desmoulins C, Dunlop NK, Gobbo F, Blakime P, Cheron G. Bowel obstruction due to ingestion of a water-absorbing bead. Arch Pediatr. 2018; 25(2):136-8

8. Forrester MB. Pediatric Orbeez ingestions reported to Texas poison centers. Pediatr Emerg Care. 2019;35(6):426-7.

9. Darracq MA, Cullen J, Rentmeester L, Cantrell FL, Ly BT. Orbeez: the magic water absorbing bead--risk of pediatric bowel obstruction? Pediatr Emerg Care. 2015;31(6):416-8.

10. Zamora IJ, Vu LT, Larimer EL, Olutoye OO. Water-absorbing balls: a "growing" problem. Pediatrics. 2012;130(4):e1011-4.

11. Sterling M, Murnick J, Mudd P. Destructive Otologic foreign body: dangers of the expanding bead. JAMA Otolaryngol Head Neck Surg. 2016;142(9): 919-20.

12. Ramgopal S, Ramprasad VH, Manole MD, Maguire RC. Expansile superabsorbent polymer ball foreign body in the ear. J Emerg Med. 2019; 56(6):e115-e7.

13. Bansil R, Turner BS. The biology of mucus: composition, synthesis and organization. Adv Drug Deliv Rev. 2018;124:3-15.

\section{Publisher's Note}

Springer Nature remains neutral with regard to jurisdictional claims in published maps and institutional affiliations.

Ready to submit your research? Choose BMC and benefit from:

- fast, convenient online submission

- thorough peer review by experienced researchers in your field

- rapid publication on acceptance

- support for research data, including large and complex data types

- gold Open Access which fosters wider collaboration and increased citations

- maximum visibility for your research: over $100 \mathrm{M}$ website views per year

At BMC, research is always in progress.

Learn more biomedcentral.com/submissions 